\title{
Lettuce Allergy Is a Lipid Transfer Syndrome-Related Food Allergy With a High Risk of Severe Reactions
}

\author{
Muñoz-García E $\mathrm{E}^{1,2,3}$, Luengo-Sánchez $0^{1,4}$, Moreno-Pérez N1,4, \\ Cuesta-Herranz J5, Pastor-Vargas $\mathrm{C}^{2 *}$, Cardona $\mathrm{V}^{1,4 *}$
}

\author{
'Allergy Section, Department of Internal Medicine, Hospital Vall d'Hebron, Barcelona, Spain \\ ${ }^{2}$ Department of Immunology, IIS- Fundación Jimenez Diaz, UAM, Madrid, Spain \\ ${ }^{3}$ Hospital Universitario de Getafe, Madrid, Spain \\ ${ }^{4}$ Allergy Research Unit, Institut de Recerca Vall d'Hebron, Barcelona, Spain \\ ${ }^{5}$ Department of Allergy, Fundación Jiménez Díaz, Madrid, Spain \\ *These authors contributed equally to this work
}

J Investig Allergol Clin Immunol 2017; Vol. 27(2): 98-103

doi: 10.18176/jiaci.0110

\begin{abstract}
Background and Objectives: Lipid transfer protein (LTP) sensitization is the most common cause of food allergy in the Mediterranean area, with peach allergy acting as the primary sensitizer in most cases. Lettuce has been described as a common offending food in patients with LTP syndrome. The aim of the study was to investigate the frequency and clinical expression of LTP syndrome in a sample of lettuceallergic patients.

Methods: We determined specific IgE to Pru 3 and lettuce in a sample of 30 patients with a diagnosis of lettuce allergy. Symptoms elicited by other LTP-containing plant-derived foods and the presence of cofactors were assessed.

Results: The clinical symptoms of lettuce allergy were frequently severe, with 18 of the 30 patients experiencing anaphylaxis. All the patients had allergic reactions to other plant foods. Cofactors were involved in the clinical reactions of 13 of the 30 patients. Sensitization to pollens was found in $90 \%$ of patients.

Conclusions: Lettuce allergy is found not as an isolated condition but in the context of LTP syndrome and it is characterized by severe reactions and frequent cofactor association.
\end{abstract}

Key words: Anaphylaxis. Cofactor. Food allergy. Lettuce allergy. Lipid transfer protein. LTP syndrome.

\section{Resumen}

Introducción y Objetivo: La sensibilización a la LTP es la causa más frecuente de alergia alimentaria en el área mediterránea, siendo la alergia al melocotón el sensibilizador primario en la mayoría de los casos. La alergia a la lechuga ha sido descrita como un manifestación frecuente en los pacientes que sufren síndrome de LTP. El objetivo del estudio fue investigar la frecuencia del síndrome de LTP en una muestra de pacientes alérgicos a lechuga y evaluar su patrón clínico.

Métodos: Se determinó la lgE específica a Pru 3 y a lechuga en una muestra de 30 pacientes con un diagnóstico de alergia a la lechuga. Se evaluaron los síntomas con otras LTPs de alimentos de origen vegetal y la presencia de cofactores.

Resultados: Los síntomas clínicos de la alergia a lechuga fueron frecuentemente graves, ya que 18/30 pacientes experimentaron anafilaxia. Todos los pacientes experimentaron reacciones alérgicas a otros alimentos vegetales. En 13/30 pacientes, los cofactores estaban implicados en las manifestaciones clínicas. Se observó que el $90 \%$ de los pacientes estaban sensibilizados a pólenes.

Conclusiones: La alergia a la lechuga más que de forma aislada, ocurre en el contexto del síndrome LTP y se caracteriza por su frecuente asociación a cofactores y la gravedad de sus reacciones.

Palabras clave: Anafilaxia. Cofactor. Alergia alimentaria. Alergia a la lechuga. LTP. Síndrome LTP. 


\section{Introduction}

Lipid transfer protein (LTP) sensitization is by far the most common cause of food allergy in the Mediterranean area [1,2], and in most cases peach allergy is the primary sensitizer $[3,4]$.

While some patients remain allergic to just 1 plant-derived food, others tend to develop sensitization or allergy to a wide variety of unrelated plant foods and/or pollens. This condition has been termed lipid transfer protein syndrome [5] and is a consequence of the high degree of IgE cross-reactivity between lipid transfer proteins (LTPs), including those that are taxonomically distant [6-8]. Among the peculiarities of this syndrome are its geographical distribution (limited to the Mediterranean area), the frequent need for cofactors to elicit clinical reactivity, and reduced severity when pollen allergy is present $[2,4]$.

It is also true that patients with LTP syndrome show a complex clinical pattern and multiple sensitizations to plant foods and pollens that complicate management [9-10]. The main offending foods reported by patients, and confirmed by sensitization in skin prick tests (SPTs), are peach (75.6\%), lettuce (48.9\%), walnut (46.7\%), and hazelnut (33.3\%) [7].

Although lettuce is one of the most frequent offending foods related to LTP syndrome, little is known about the peculiarities of lettuce allergy, as there have been few case reports and only 3 cases series have been described to date [11-13]. The aim of this study was to define the clinical characteristics of lettuce allergy and the frequency of LTP syndrome in a cohort of lettuce-allergic patients.

\section{Materials and Methods}

Patients referred with suspected food allergy to the outpatient clinic of Hospital Vall d'Hebron in Barcelona, Spain between 2010 and 2011 were studied. Lettuce allergy was diagnosed in patients with a clear history of adverse reactions suggestive of IgE-mediated allergy, along with a positive skin prick test (SPT) and/or food challenge test, in accordance with the diagnostic algorithm described by Ibañez et al [14]. Patients with severe systemic reactions to lettuce or with typical, recent, repeated, and unequivocal reactions to lettuce, with positive skin tests, did not undergo a diagnostic oral challenge test. Cofactor-enhanced food allergy was diagnosed according to a protocol proposed by our group [15].

Symptoms elicited by other LTP-containing plant foods and the presence of cofactors were recorded. LTP syndrome was defined as sensitization to Prup 3 (peach LTP) and symptoms induced by 2 or more unrelated plant foods. A detailed clinical history of symptoms related to other plant foods was recorded for all patients using the same criteria as described above. The protocol was approved by the hospital's ethics committee and patients provided informed consent to be included in the study.

SPTs were performed using commercials extracts of romaine lettuce (LETI Laboratories, S.L., Barcelona, Spain) and peach (ALK-Abello Laboratories, Madrid, Spain). For skin prick-to-prick tests, a lancet was pricked into the fresh leaves of different varieties of lettuce just before it was pricked into the skin, according to the standard method [16]. SPTs were also performed according to standard procedures with common commercial panels of plant-food allergenic sources and pollens present in our area (plane tree, mugwort, grass, wall pellitory, olive, cypress). Specific IgE to lettuce and Pru p 3 were determined by ImmunoCAP (Phadia, Thermo Fisher Scientific) and/or ImmunoCAP-ISAC 103 or 112 (Phadia, Thermo Fisher Scientific).

Specific IgE to Lac s 1 (lettuce LTP) had been qualitatively assessed by means of immunoblotting and mass spectrometry analysis in a previous study by our group [13].

\section{Results}

Thirty lettuce-allergic patients ( 21 females and 9 males), with an average age of 30.5 years (range, 16-60 years), were included. Their clinical features are shown in Table 1.

Clinical symptoms to lettuce were predominantly severe, with $60 \%$ of patients $(18 / 30)$ experiencing anaphylaxis after lettuce ingestion (Table 2), mainly in the context of cofactor involvement (13/18). Altogether anaphylactic reactions induced by cofactors accounted for $43 \%$ of the reactions; exercise was the most common cofactor (53.8\%), followed by nonsteroidal anti-inflammatory drugs (NSAIDs) (23\%). In 3 patients more than 1 of the cofactors considered (NSAIDs, exercise, and alcohol) was involved.

Oral allergy syndrome and urticaria/angioedema were reported for $20 \%$ and $10 \%$ of the patients respectively and 3 patients $(10 \%)$ reported gastrointestinal complaints only (Table 2).

Lettuce sIgE was negative in 11 patients, and overall, the positive levels were low with a median of $0.99 \mathrm{kU} / \mathrm{L}$ (range, 0.11-5.97).

Lac s 1 recognition by immunoblotting was found in $80 \%$ of patients in a previous study by our group (Table 1). In addition, specific IgE to Pru 3 measured by ImmunoCAP was positive in all but 1 patient.

Serum from 24 of the 30 patients was available to perform ImmunoCAP-ISAC; the 103-ISAC panel was used in 15 cases and the more recent 112-ISAC panel in 9. Sensitization to at least 2 LTPs in the panel (Pru p 3, Ara h 9, Jug r 3, Cor a 8, Art $\vee 3$, and Pla a 3) was observed in $87 \%$ of cases; the distribution of frequencies is shown in Table 3. Just 3 patients were sensitized to other plant food allergens in the microarray panel (profilin, Bet-v1 homologues, thaumatin, calciumbinding protein, vicilin, 2s-albumin, 11-s albumin, gliadin, papain-like cysteine protease, and expansin). One patient was sensitized to kiwi thaumatin-like protein (TLP) and 2 patients, both with grass pollinosis, were sensitized to profilins.

Sensitization to pollens was found in $90 \%$ of patients, $86 \%$ of whom reported rhinitis and/or asthma symptoms. Of the pollen-sensitized patients, $76.7 \%$ were sensitized to plane tree and $60 \%$ to mugwort; these pollens are known to contain LTP. Polysensitization to pollens and other plant foods was not associated with reaction severity.

All patients were sensitized to plant foods other than lettuce, and most of them (90\%) had a previous history of allergic reactions to other plant foods, mainly stone fruits (Rosaceae) and tree nuts (Table 4). The remaining 10\% had experienced their first reaction with lettuce and had subsequently developed symptoms with other plant foods. 
Table 1. Clinical Features and in Vitro Sensitization of Lettuce-Allergic Patients

\begin{tabular}{|c|c|c|c|c|c|c|c|c|c|}
\hline Patient & $\begin{array}{l}\text { Age, } \\
y\end{array}$ & Sex & $\begin{array}{l}\text { Symptoms Upon } \\
\text { Lettuce Ingestion }\end{array}$ & $\begin{array}{l}\text { Sensitization to } \\
\text { Other Plant Foods }\end{array}$ & $\begin{array}{l}\text { Sensitization to } \\
\text { Pollens }\end{array}$ & $\begin{array}{l}\text { Total IgE, } \\
\text { kU/L }\end{array}$ & $\begin{array}{l}\text { Lettuce sIgE, } \\
\mathrm{kU} / \mathrm{L}\end{array}$ & $\underset{\text { sIgE }}{\text { rPru p } 3}$ & $\begin{array}{l}\text { Lettuce Allergen } \\
\text { Recognition }^{\mathrm{a}}\end{array}$ \\
\hline 1 & 43 & $\mathrm{M}$ & CEFA NSAID & $\mathrm{Be}, \mathrm{L}, \mathrm{Ro}$ & P1 & 52 & 0.39 & $4.3 \mathrm{ISU}$ & LTP \\
\hline 2 & 56 & M & CEFA OH & L, Ro, N & $\mathrm{Pl}, \mathrm{Ar}$ & 316 & 1.06 & $3.5 \mathrm{ISU}$ & TLP \& AP \\
\hline 3 & 23 & $\mathrm{~F}$ & CEFA EX & Ro, N, To & $\mathrm{Pl}, \mathrm{Ar}$ & 92.1 & 0.51 & $4.6 \mathrm{kU} / \mathrm{L}$ & LTP \& TLP \& AP \\
\hline 4 & 34 & $\mathrm{M}$ & CEFA EX & $\mathrm{Ce}, \mathrm{Ro}, \mathrm{N}$ & Ar, G, P & 366 & 0.91 & $16.9 \mathrm{kU} / \mathrm{L}$ & LTP \\
\hline 5 & 21 & $\mathrm{~F}$ & CEFA EX & $\mathrm{Ki}, \mathrm{Ro}, \mathrm{N}$ & $\mathrm{Pl}, \mathrm{Ar}$ & 25 & 0.61 & 33 ISU & LTP \& TLP \& AP \\
\hline 6 & 42 & $\mathrm{~F}$ & CEFA EX & Ro & - & 15.5 & 0 & $3.5 \mathrm{ISU}$ & LTP \& TLP \& AP \\
\hline 7 & 60 & $\mathrm{~F}$ & CEFA NSAID/OH & $\mathrm{Pe}, \mathrm{Ro}, \mathrm{N}, \mathrm{Me}$ & $\mathrm{P}$ & 27 & 0.15 & 0 & TLP \& AP \\
\hline 8 & 41 & $\mathrm{~F}$ & CEFA NSAID & Ro, N, Me & $\mathrm{Pl}, \mathrm{Ar}$ & 26 & 0.26 & 1.9 ISU & LTP \\
\hline 9 & 22 & $\mathrm{~F}$ & CEFA EX & Ro, $\mathrm{N}$ & G & 2078 & 2.54 & 48 ISU & LTP \& TLP \& AP \\
\hline 10 & 45 & M & CEFA NSAID & L, Ro, N, To & Pl & 120 & 0.06 & $1.02 \mathrm{kU} / \mathrm{L}$ & LTP \& TLP \& AP \\
\hline 11 & 25 & $\mathrm{~F}$ & CEFA EX & $\mathrm{N}, \mathrm{Mu}, \mathrm{Ba}$ & $\mathrm{Ar}, \mathrm{G}, \mathrm{P}, \mathrm{O}$ & 177 & 3.86 & 11 ISU & LTP \& TLP \& AP \\
\hline 12 & 30 & M & CEFA NSAID/EX & Ro, $\mathrm{N}$ & $\mathrm{Pl}, \mathrm{Ar}, \mathrm{G}, \mathrm{Cu}, \mathrm{O}$ & 149 & 2.74 & $43.3 \mathrm{kU} / \mathrm{L}$ & LTP \\
\hline 13 & 16 & $\mathrm{~F}$ & CEFA EX & $\begin{array}{l}\mathrm{Be}, \mathrm{Ce}, \mathrm{N} \\
\mathrm{Mu}, \mathrm{To}\end{array}$ & $\begin{array}{l}\text { Pl, Cyn, P, } \\
\text { Phrg, Mer, O }\end{array}$ & 79 & 4.3 & NR & LTP \& TLP \& AP \\
\hline 14 & 30 & $\mathrm{~F}$ & GI & $\mathrm{Ki}, \mathrm{Ro}, \mathrm{N}$ & $\mathrm{Pl}$ & 54 & 0 & $2.08 \mathrm{kU} / \mathrm{L}$ & TLP \& AP \\
\hline 15 & 33 & $\mathrm{~F}$ & GI & $\mathrm{L}, \mathrm{Ro}, \mathrm{N}, \mathrm{Mu}$ & $\mathrm{Pl}, \mathrm{Ar}$ & 71.4 & 0.31 & 11 ISU & LTP \\
\hline 16 & 23 & $\mathrm{~F}$ & GI & $\begin{array}{l}\mathrm{Ce}, \mathrm{Ro}, \mathrm{N}, \\
\text { Gra, Me }\end{array}$ & - & 23 & 0.42 & $2.5 \mathrm{ISU}$ & LTP \\
\hline 17 & 19 & $\mathrm{~F}$ & $\mathrm{AF}$ & $\begin{array}{c}\mathrm{L}, \mathrm{Ce}, \mathrm{Ro}, \mathrm{N}, \\
\mathrm{Mu}, \mathrm{Av}\end{array}$ & $\begin{array}{l}\text { Pl, G, Phrg, } \\
\text { Cu, Ptg }\end{array}$ & 78 & 0.10 & $0.56 \mathrm{kU} / \mathrm{L}$ & LTP \\
\hline 18 & 31 & $\mathrm{~F}$ & $\mathrm{AF}$ & Ro, N, To & $\mathrm{Pl}, \mathrm{Ar}, \mathrm{G}$ & 148 & 1.81 & $2.3 \mathrm{ISU}$ & LTP \& TLP \& AP \\
\hline 19 & 24 & $\mathrm{~F}$ & $\mathrm{AF}$ & $\mathrm{L}, \mathrm{N}$ & $\mathrm{Pl}, \mathrm{Ar}$ & 131 & 0.96 & $1.3 \mathrm{ISU}$ & LTP \\
\hline 20 & 39 & $\mathrm{M}$ & $\mathrm{AF}$ & L, Ro, N, To & - & 701 & 2.06 & $26.10 \mathrm{kU} / \mathrm{L}$ & TLP \& AP \\
\hline 21 & 29 & $\mathrm{~F}$ & $\mathrm{AF}$ & $\begin{array}{c}\text { Be, Ro, Gra, } \\
\text { To, Ba }\end{array}$ & Pl & 198 & 0.11 & $2.8 \mathrm{ISU}$ & LTP \& TLP \& AP \\
\hline 22 & 29 & $\mathrm{~F}$ & SAO & $\begin{array}{l}\mathrm{L}, \mathrm{Pe}, \mathrm{Ki}, \mathrm{Ro}, \mathrm{N}, \\
\quad \mathrm{Mu}, \mathrm{To}, \mathrm{On}\end{array}$ & $\mathrm{Pl}, \mathrm{Ar}, \mathrm{O}, \mathrm{Ptg}$ & 121 & 1.36 & $1.5 \mathrm{ISU}$ & LTP \& TLP \& AP \\
\hline 23 & 44 & M & SAO & Ro, $\mathrm{N}$ & $\mathrm{Pl}, \mathrm{Ar}, \mathrm{P}$ & 236 & 0.32 & $7.1 \mathrm{ISU}$ & LTP \\
\hline 24 & 29 & $\mathrm{~F}$ & $\mathrm{SAO}$ & $\begin{array}{l}\text { Ce, Ro, N, } \\
\text { Mu, To }\end{array}$ & $\begin{array}{c}1, \mathrm{Ar} \\
\mathrm{P}\end{array}$ & 54 & 1.2 & $9.52 \mathrm{kU} / \mathrm{L}$ & LTP \& TLP \& AP \\
\hline 25 & 22 & $\mathrm{~F}$ & SAO & Ro, N, To & $\mathrm{Pl}$ & 414 & 0.99 & $11 \mathrm{ISU}$ & TLP \& AP \\
\hline 26 & 37 & $\mathrm{~F}$ & SAO & $\mathrm{L}, \mathrm{Ro}, \mathrm{N}, \mathrm{Me}, \mathrm{Av}$ & $\mathrm{Pl}, \mathrm{Ar}$ & 64 & 0.06 & $4.52 \mathrm{kU} / \mathrm{L}$ & LTP \\
\hline 27 & 24 & $\mathrm{M}$ & SAO & Ro, $\mathrm{N}$ & $\mathrm{Pl}, \mathrm{Ar}, \mathrm{P}$ & 220 & 1.96 & 85 ISU & LTP \\
\hline 28 & 35 & $\mathrm{~F}$ & $\mathrm{U} / \mathrm{AE}$ & $\begin{array}{l}\text { L, Pe, Ce, Ro, } \\
\quad \text { N, Me, Fi }\end{array}$ & $\begin{array}{c}\mathrm{Pl}, \mathrm{Ar}, \mathrm{G}, \mathrm{P}, \mathrm{Phrg}, \\
\mathrm{Cu}, \mathrm{O}, \mathrm{Ptg}, \mathrm{Mer}\end{array}$ & 74 & 0.14 & 0 & LTP \& TLP \& AP \\
\hline 29 & 44 & M & $\mathrm{U} / \mathrm{AE}$ & $\mathrm{Be}, \mathrm{Ro}, \mathrm{N}$ & $\mathrm{Pl}, \mathrm{Ar}, \mathrm{G}, \mathrm{O}$ & 1091 & 5.97 & $21 \mathrm{ISU}$ & LTP \& TLP \& AP \\
\hline 30 & 38 & $\mathrm{~F}$ & $\mathrm{U} / \mathrm{AE}$ & $\mathrm{Ki}, \mathrm{Ro}, \mathrm{N}$ & $\mathrm{Pl}, \mathrm{Ar}, \mathrm{P}$ & 37 & 2.71 & 16 ISU & TLP \& AP \\
\hline
\end{tabular}

Abbreviations: Symptoms: AE, angioedema; AF, anaphylaxis; CEFA, cofactor-enhanced food allergy; GI, gastrointestinal symptoms; OAS, oral allergy syndrome; U, urticaria. Aeroallergens: Ar, Artemisia; Cu, Cupressus; Cyn, Cynodon; G, grass mix; Mer, Mercurialis; O, Olea; P, Parietaria; Pl, plane tree; Ptg, Plantago; Phrg, Phragmites. Foods: Av, avocado; Ba, banana; Be, green bean; Ce, cereals; Fi, fig; Gra, grape; Ki, kiwi; L, legume; Me, melon; Mu, mustard; N, nuts; On, onion; Pe, green pepper; Ro, Rosaceae fruits; To, tomato. Lettuce allergens: LTP, lipid transfer protein; TLP, thaumatin-like protein; AP, aspartyl protease. Units: ISU, ISAC standardized units; slgE, specific lgE.

${ }^{a}$ As previously described in Munoz-Garcia E, Luengo-Sanchez O, Haroun-Diaz E, Maroto AS, Palacin A, Diaz-Perales A, de las Heras GM, LabradorHorrillo M, Vivanco F, Cuesta-Herranz J, Pastor-Vargas C. Identification of thaumatin-like protein and aspartyl protease as new major allergens in lettuce (Lactuca sativa). Mol Nutr Food Res. 2013;57:2245-52. 
Table 2. Symptoms Elicited by Lettuce Allergy

\begin{tabular}{lc}
\hline Lettuce Symptoms & $\%$ (No./Total) \\
\hline Anaphylaxis & $60(18 / 30)$ \\
- CEFA & $43.3(13 / 30)$ \\
Exercise & $7 / 13$ \\
NSAID & $3 / 13$ \\
Alcohol & $1 / 13$ \\
$>1$ of above cofactors & $2 / 13$ \\
Oral allergy syndrome & $20 \%(6 / 30)$ \\
Gastrointestinal symptoms & $10 \%(3 / 30)$ \\
Urticaria/angioedema & $10 \%(3 / 30)$
\end{tabular}

Abbreviations: CEFA, cofactor-enhanced food allergy; NSAID, nonsteroidal anti-inflammatory drug.

Table 3. Frequency of Sensitization to Lipid Transfer Proteins, Profilins, and Bet v1 Homologues by Immunocap-ISAC

\begin{tabular}{lccc}
\hline Allergen & $\begin{array}{c}\text { ISAC 103 } \\
\text { No. Positive } \\
\text { Results/Total }\end{array}$ & $\begin{array}{c}\text { ISAC 112 } \\
\text { No. Positive } \\
\text { Results/Total }\end{array}$ & $\begin{array}{c}\text { Overall } \\
\text { Sensitization, } \\
\%\end{array}$ \\
\hline Pru p 3 & $14 / 15$ & $7 / 9$ & $87.5 \%$ \\
Jug r 3 & NP & $7 / 9$ & $78 \%$ \\
Ara h 9 & NP & $6 / 9$ & $67 \%$ \\
Cor a 8 & $10 / 15$ & $4 / 9$ & $44 \%$ \\
Pla a 3 & NP & $7 / 9$ & $87.5 \%$ \\
Art v 3 & $10 / 15$ & $4 / 9$ & $44 \%$ \\
Bet v1 homologues & $0 / 15$ & $0 / 9$ & $0 \%$ \\
Profilins & $0 / 15$ & $2 / 9$ & $8.3 \%$ \\
\hline
\end{tabular}

Abbreviation: NP, not present.

Table 4. Concomitant Plant Food Sensitizations

\begin{tabular}{lc}
\hline Other Plant Foods & $\%$ (No./Total) \\
\hline Peach & $90(27 / 30)$ \\
Tree nuts & $90(27 / 30)$ \\
Legumes & $33.3(10 / 30)$ \\
Tomato & $30(9 / 30)$ \\
Cereals & $20(6 / 30)$ \\
Mustard & $20(6 / 30)$ \\
Melon & $16.66(5 / 30)$ \\
Runner bean & $13.33(4 / 30)$
\end{tabular}

With 1 exception, all the patients were sensitized to peach (positive SPT and/or sIgE), with symptoms ranging from contact urticaria to anaphylaxis. Allergic reactions to peach were predominantly mild, with half of the patients experiencing only oral allergy symptoms or contact urticaria (Table 5).
Table 5. Symptoms Elicited by Peach

\begin{tabular}{lc}
\hline Symptoms & $\%($ No./Total $)$ \\
\hline Oral allergy syndrome & $30(9 / 30)$ \\
Urticaria/angioedema & $13.3(4 / 30)$ \\
Peel contact urticaria & $26.6(8 / 30)$ \\
Anaphylaxis & $16.66(5 / 30)$ \\
Asymptomatic sensitization & $10(3 / 30)$ \\
No peach sensitization & $3.3(1 / 30)$
\end{tabular}

Considering that 29 of the 30 lettuce-allergic patients were sensitized to Prup 3 and that all of them were sensitized to and reported symptoms with more than 2 unrelated plant foods, $96.6 \%$ of the sample were considered to have LTP syndrome.

\section{Discussion}

In our population, lettuce allergy occurred in the context of LTP syndrome. Our results indicate that lettuce allergy is mostly due to sensitization to LTP ( $\operatorname{Lac~s~1),~supporting~}$ previous reports [11], and seems to be driven by peach allergy. In most cases, patients reported having experienced reactions with peach prior to developing symptoms with lettuce and the majority had positive sIgE to peach LTP (Pru p 3), with proven cross-reactivity with lettuce LTP. Taken together, these observations suggest that peach acted as the primary sensitizer.

Lettuce allergy is an increasingly common condition in our population. Lettuce has several peculiarities that frequently impede its being recognized as responsible for an allergic reaction. First, it is seldom eaten alone and reactions normally occur after eating a salad containing not only lettuce but other vegetables all containing LTP. Second, in many cases, a cofactor (mainly exercise or a NSAID) is needed to elicit the reaction, and consequently, patients may tolerate lettuce or experience only mild symptoms on a regular basis when exercise and NSAID are not present in the hours preceding or following intake. Clinical expression of sensitization is thus extremely variable, and is seemingly dependent on the presence/ absence of a number of cofactors [4]. This implies that the presence of cofactors should always be assessed when studying a possible case of lettuce allergy and that tolerance after an index reaction does not rule out lettuce allergy [15,17-19].

ImmunoCAP seems to have very low sensitivity to lettuce sIgE, probably due to the low allergen content (not only of Lac s 1) in lettuce extracts.

All the patients in our series reported adverse reactions to other LTP-containing plant foods, mostly stone fruits (Rosaceae) and tree nuts. Interestingly, only 5 patients had anaphylactic reactions to peach; the rest had mild symptoms. This may be because patients generally avoid peach after the first reaction but continue to eat other LTP-containing plant foods.

Lettuce LTP was found to be the major allergen in our series, supporting previous reports [13]. However, while this LTP was recognized in $80 \%$ of lettuce-allergic patients, peach LTP was recognized in an even higher proportion and 
$87 \%$ of patients had positive results to more than 2 LTPs in the ISAC microarray. Similar results have been observed in peanut-allergic patients in Spain. The patients had both higher levels and a higher frequency of recognition of Pru p 3 than Ara h 9 and many of them had a previous history of peach allergy [20]. The inhibition assays indicated that Prup 3 was the primary sensitizer.

In our study, the hypothesis of peach-driven lettuce allergy is supported by both clinical history and a higher frequency of Pru p 3 sensitization. Further inhibition studies, however, are needed to confirm this.

It is striking that $90 \%$ of our patients were sensitized to pollen. An association between LTP-mediated food allergy and pollinosis has been described in the Mediterranean area [1-21] mainly with pollen LTP from plane tree (Pla a 3) [7,12,22-24] and mugwort (Art v 3) [25-31]. The high prevalence of sensitization to these pollens in our patients-76\% and $60 \%$, respectivelysupports the hypothesis of LTP and food pollen syndrome in our area $[3,28]$. However, as the aim of our study was to characterize a sample of lettuce-allergic patients, we did not include a control group and were therefore unable to perform association studies.

Lettuce was not the first food trigger of an allergic reaction in most of the patients in our series, but it became part of the LTP syndrome. Lettuce allergy must therefore be considered when evaluating patients with multiple plant food allergies. Furthermore, we recommend that lettuce-allergic patients avoid cofactors because of the high risk of severe reactions.

Taken together, the findings of this study provide insight into the peculiarities of lettuce allergy, which is mostly due to sensitization to LTP and seems to be driven by peach allergy. In the majority of cases, lettuce was not the first offending food but it became part of the LTP syndrome, eliciting severe allergic reactions frequently enhanced by concomitant cofactors.

\section{Funding}

This work was supported by grants from the Instituto de Salud Carlos III (PI10/00974 and PI13/00928) and RETIC Red de Investigación de Reacciones Adversas a Alérgenos y Fármacos (RD12/0013/0013, RD12/0013/0014, and RD12/0013/0015), co-supported by FEDER grants.

\section{Conflicts of Interest}

The authors declare that they have no conflicts of interest.

\section{References}

1. Salcedo G, Sanchez-Monge R, Diaz-Perales A, Garcia-Casado G, Barber D. Plant non-specific lipid transfer proteins as food and pollen allergens. Clin Exp Allergy. 2004;34:1336-41.

2. Cuesta-Herranz J, Barber D, Blanco C, Cistero-Bahima $A$ Crespo JF, Fernandez-Rivas M, Fernandez-Sanchez J, Florido JF, Ibanez MD, Rodriguez R, Salcedo G, Garcia BE, Lombardero M, Quiralte J, Rodriguez J, Sanchez-Monge R, Vereda A, Villalba M, Alonso Diaz de Durana MD, Basagana M, Carrillo T, Fernandez-Nieto M, Tabar Al. Differences among pollenallergic patients with and without plant food allergy. Int Arch Allergy Immunol. 2010;153:182-92.
3. Palacin A, Gomez-Casado C, Rivas LA, Aguirre J, Tordesillas L, Bartra J, Blanco C, Carrillo T, Cuesta-Herranz J, de FC, AlvarezEire GG, Fernandez FJ, Gamboa P, Munoz R, Sanchez-Monge $\mathrm{R}$, Sirvent $\mathrm{S}$, Torres MJ, Varela-Losada S, Rodriguez R, Parro V, Blanca M, Salcedo G, Diaz-Perales A. Graph based study of allergen cross-reactivity of plant lipid transfer proteins (LTPS) using microarray in a multicenter study. PLOS One. 2012; 7:e50799.

4. Asero R, Pravettoni V. Anaphylaxis to plant-foods and pollen allergens in patients with lipid transfer protein syndrome. Curr Opin Allergy Clin Immunol. 2013;13:379-85.

5. Pastorello EA, Robino AM. Clinical role of lipid transfer proteins in food allergy. Mol Nutr Food Res. 2004;48:356-62.

6. Asero R, Mistrello G, Roncarolo D, Amato S, Caldironi G, Barocci F, van RR. Immunological cross-reactivity between lipid transfer proteins from botanically unrelated plant-derived foods: a clinical study. Allergy. 2002;57:900-6.

7. Pascal M, Munoz-Cano R, Reina Z, Palacin A, Vilella R, Picado C, Juan M, Sanchez-Lopez J, Rueda M, Salcedo G, Valero A, Yague J, Bartra J. Lipid transfer protein syndrome: clinical pattern, cofactor effect and profile of molecular sensitization to plant-foods and pollens. Clin Exp Allergy. 2012;42:152939.

8. Tordesillas L, Sirvent S, Diaz-Perales A, Villalba M, CuestaHerranz J, Rodriguez R, Salcedo G. Plant lipid transfer protein allergens: no cross-reactivity between those from foods and olive and Parietaria pollen. Int Arch Allergy Immunol. 2011;156:291-6.

9. Scala E, Till SJ, Asero R, Abeni D, Guerra EC, Pirrotta L, Paganelli R, Pomponi D, Giani M, De PO, Cecchi L. Lipid transfer protein sensitization: reactivity profiles and clinical risk assessment in an Italian cohort. Allergy. 2015;70:933-43.

10. Uasuf CG, Villalta D, Conte ME, Di SC, Barrale M, Cantisano V, Pace E, Gjomarkaj M, Gangemi S, Brusca I. Different cosensitizations could determine different risk assessment in peach allergy? Evaluation of an anaphylactic biomarker in Pru p 3 positive patients. Clin Mol Allergy. 2015;13:30.

11. Hartz C, San Miguel-Moncin MM, Cistero-Bahima A, Fotisch K, Metzner KJ, Fortunato D, Lidholm J, Vieths S, Scheurer S. Molecular characterisation of Lac s 1, the major allergen from lettuce (Lactuca sativa). Mol Immunol. 2007;44:2820-30.

12. San Miguel-Moncin M, Krail M, Scheurer S, Enrique $E$, Alonso R, Conti A, Cistero-Bahima A, Vieths S. Lettuce anaphylaxis: identification of a lipid transfer protein as the major allergen. Allergy. 2003;58:511-7.

13. Munoz-Garcia E, Luengo-Sanchez O, Haroun-Diaz E, Maroto AS, Palacin A, Diaz-Perales A, de las Heras GM, LabradorHorrillo M, Vivanco F, Cuesta-Herranz J, Pastor-Vargas C. Identification of thaumatin-like protein and aspartyl protease as new major allergens in lettuce (Lactuca sativa). Mol Nutr Food Res. 2013;57:2245-52.

14. Ibanez MD, Alonso E, Blanco C, Cistero A, Cuesta-Herranz $J$, Fernandez-Rivas $M$, Florido JF, Garcia BE, Laffond $E$, Martin MF, Nieto A, Rico MA, Rodriguez J. Metodología diagnóstica en la alergia a alimentos. Alergol Inmunol Clin. 1999; 14(2):50-62.

15. Cardona $V$, Luengo $O$, Garriga $T$, Labrador-Horrillo $M$, SalaCunill A, Izquierdo A, Soto L, Guilarte M. Co-factor-enhanced food allergy. Allergy. 2012;67:1316-8. 
16. Skin tests used in type I allergy testing Position paper. SubCommittee on Skin Tests of the European Academy of Allergology and Clinical Immunology. Allergy. 1989;44 Suppl 10:1-59.

17. Wolbing F, Fischer J, Koberle M, Kaesler S, Biedermann T. About the role and underlying mechanisms of cofactors in anaphylaxis. Allergy. 2013;68:1085-92.

18. Niggemann B, Beyer K. Factors augmenting allergic reactions. Allergy. 2014;69:1582-7.

19. Romano A, Scala E, Rumi G, Gaeta F, Caruso C, Alonzi C, Maggioletti M, Ferrara R, Palazzo P, Palmieri V, Zeppilli P, Mari A. Lipid transfer proteins: the most frequent sensitizer in Italian subjects with food-dependent exercise-induced anaphylaxis. Clin Exp Allergy. 2012;42:1643-53.

20. Javaloyes G, Goikoetxea MJ, García Nuñez I, Aranda A, Sanz ML, Blanca M, Diaz Perales A, da Souza J, Esparza I, del Pozo V, Blazquez AB, Scheurer S, Vieths S, Ferrer M. Pru p 3 acts as a strong sensitizer for peanut allergy in Spain. J Allergy Clin Immunol. 2012;130(6):1432-4.

21. Zuidmeer $L$, van RR. Lipid transfer protein allergy: primary food allergy or pollen/food syndrome in some cases. Curr Opin Allergy Clin Immunol. 2007;7:269-73.

22. Lauer I, Miguel-Moncin MS, Abel T, Foetisch K, Hartz C, Fortunato D, Cistero-Bahima A, Vieths $S$, Scheurer S. Identification of a plane pollen lipid transfer protein (Pla a 3 ) and its immunological relation to the peach lipid-transfer protein, Pru p 3. Clin Exp Allergy. 2007;37:261-9.

23. Enrique E, Cistero-Bahima A, Bartolome B, Alonso R, San Miguel-Moncin MM, Bartra J, Martinez A. Platanus acerifolia pollinosis and food allergy. Allergy. 2002;57:351-6.

24. Miralles JC, Caravaca F, Guillen F, Lombardero M, Negro JM. Cross-reactivity between Platanus pollen and vegetables. Allergy. 2002;57:146-9.

25. Sanchez-Lopez J, Tordesillas L, Pascal M, Munoz-Cano R, Garrido M, Rueda M, Vilella R, Valero A, Diaz-Perales A, Picado C, Bartra J. Role of Art $v 3$ in pollinosis of patients allergic to Pru p 3. J Allergy Clin Immunol. 2014;133:1018-25.

26. Gadermaier G, Harrer A, Girbl T, Palazzo P, Himly M, Voge L, Briza P, Mari A, Ferreira F. Isoform identification and characterization of Art $\vee 3$, the lipid-transfer protein of mugwort pollen. Mol Immunol. 2009;46:1919-24.
27. Lombardero M, Garcia-Selles FJ, Polo F, Jimeno L, Chamorro MJ, Garcia-Casado G, Sanchez-Monge R, Diaz-Perales A, Salcedo $G$, Barber D. Prevalence of sensitization to Artemisia allergens Art v 1, Art v 3 and Art v 60 kDa. Cross-reactivity among Art v 3 and other relevant lipid-transfer protein allergens. Clin Exp Allergy. 2004;34:1415-21.

28. Diaz-Perales A, Lombardero $M$, Sanchez-Monge $R$, GarciaSelles FJ, Pernas M, Fernandez-Rivas M, Barber D, Salcedo G. Lipid-transfer proteins as potential plant panallergens: crossreactivity among proteins of Artemisia pollen, Castanea nut and Rosaceae fruits, with different IgE-binding capacities. Clin Exp Allergy. 2000;30:1403-10.

29. Garcia-Selles FJ, Diaz-Perales A, Sanchez-Monge R, Alcantara M, Lombardero M, Barber D, Salcedo G, Fernandez-Rivas M. Patterns of reactivity to lipid transfer proteins of plant foods and Artemisia pollen: an in vivo study. Int Arch Allergy Immunol. 2002;128:115-22.

30. Pastorello EA, Pravettoni V, Farioli L, Rivolta F, Conti A, Ispano $M$, Fortunato $D$, Bengtsson A, Bianchi M. Hypersensitivity to mugwort (Artemisia vulgaris) in patients with peach allergy is due to a common lipid transfer protein allergen and is often without clinical expression. J Allergy Clin Immunol. 2002;110:310-7.

31. Egger $M$, Hauser $M$, Mari A, Ferreira F, Gadermaier $G$. The role of lipid transfer proteins in allergic diseases. Curr Allergy Asthma Rep. 2010;10:326-335.

- Manuscript received March 28, 2016; accepted for publication, September 8, 2016.

\section{- Carlos Pastor Vargas}

Department of Immunology

Hospital Fundación Jiménez Diaz

Avda. Reyes Católicos 2

28040 Madrid, Spain

E-mail: cpastor@fjd.es 